\title{
Implementation E-Tilang in Bandung to Increase Awareness of Cross as Moral Law Passed Citizenship (Civic Virtue)
}

\author{
Ghina Aisyah and Prayoga Bestari \\ Citizenship Education, Graduate School \\ Universitas Pendidikan Indonesia \\ Bandung, Indonesia \\ ghinaaisyah5@gmail.com
}

\begin{abstract}
This research is motivated by the problems associated with legal awareness because a lot of people who commit traffic offenses which raises the number of highway accidents, The lack of public awareness in complying with and implementing legislation of traffic, making the rate of accidents in the city of Bandung has increased, problems related to traffic violations, among others motorcyclists not wearing a helmet, riders who do not carry driver's license, a motorist who did not using a seat belt, disobeying traffic signs, to overcome these problems, one of the ways used by Polrestabes duo with implementing E-ticket. This study aims to describe the implementation of the e-ticket in the city of Bandung in increasing awareness of traffic laws as moral citizenship (civic virtue), this study used a qualitative approach with descriptive analytical method. The findings in this study indicate that the implementation of the E-ticket in the city of Bandung in increasing awareness of the law of traffic as moral citizenship (civic virtue), has been performing well, but still found a variety of problems one of which is still many people who do not understand about technology other than that, more people want a ticket manually, because by implementing e-ticketed people in charge to pay by bank. It needs the support and encouragement from various parties that exist in society and also Polrestabes that e-ticket can be well.
\end{abstract}

Keywords-implementation of e-tilang; awareness of the law; civic virtue

\section{PRELIMINARY}

Technological advances and current information have led to the rapid development of transportation facilities are in Indonesia is causing traffic congestion. The development of transportation facilities either motorcycles or cars make people competing to have it, more and more people have private transportation makes it increasingly dense traffic flow on the highway and make the level of accidents is increasing. The main factor is the cause of the high number of traffic accidents by Sugiyanto "i.e. the growth of motor vehicles, especially motorcycles". Other factors that because accidents occur at traffic in result because there are many people who are not orderly in traffic. Traffic order is not only the responsibility of the police alone, but people also have the same responsibility in maintaining traffic order as stipulated in Law No. 22 Year
2009 regarding Traffic and Road Transportation Article 258 which states that "the Community shall participate in the maintenance of infrastructure, roads, development of discipline and ethics of traffic, and participate in the maintenance Security, Safety, Public Order and Smooth Traffic and Transportation" [1]. Society should really pay attention, understand and implement the traffic rules, so as to reduce accidents on the highway, due to negligence and lack of tertiban be undertaken either by the driver or the pedestrian.

Based on data from traffic accidents in the year 2015-2016 dibandung based duo road safety annual report, the accident data by injury and death by age group $49.2 \%$ injury per 100.000 population comes from age 15-24 and the accident which caused the death of $8.9 \%$ of which comes from age $15-24$. It is in the causes for the population in the higher duo thus also affecting the increased mobility of participating rises, so does the rate of death due to accident. According to who, the highway has claimed no fewer than 1.2 million lives each year due to accidents that occur worldwide. Globally traffic accidents are also the leading cause of death in young age 1529 years. Nowadays a lot of people and students who are not yet old enough already riding a motorcycle with violating the rules of conduct traffic and a lack of understanding of the rules of traffic for example, riding a motorcycle without a driver's license (SIM), lift is not wearing a helmet, do not turn on the lights in daytime day, not using a seat belt in driving etc. The number of traffic violations committed in society in Indonesia shows the moral degradation. According Winataputra and Budimansyah moral crisis that hit the Indonesian nation as follows:

"The violence, traffic violations, public lies, arrogance of power, the collective corruption, collusion with clothes professionalism, nepotism, local and institutional, abuse of authority, conflicts between religious communities, forgery izasah, conflict laborers by employers, the conflict between the people and the ruler, demonstration disrupting inter-party coalition contextually and seasonal, political fraud in the implementation of national and local elections, regional autonomy is impacting the growth of ethnocentrism and others " [2]. 
In Polrestabes Bandung in raising legal awareness orderly traffic in the city of Bandung has been applied to an e-ticket, Program e-ticket or a ticket online is based on Article 272 of Law Number 22 Year 2009 regarding Traffic and Road Transportation, which mentions that: to support enforcement activities in the field of traffic violations and road transport, can be used electronic equipment [1]. The results of the use of electronic equipment that could be used as evidence in court. And also, in the ITE Law Article 5, which states that the recognition of information / electronic documents as valid legal evidence. Which in principle is an extension of the evidence is set in the Code of Criminal Procedure Article 184. The ETilang will be able to become flagship programs in building a culture of orderly traffic, improve safety and lower the quality of fatality victims laka, build orderly traffic culture, education and various other things to happen and the maintenance of security, safety, order and smooth traffic (Kamseltibcar So). With the E-ticketed easier for people to pay fines through banks. E-ticket is the effort devoted to the public so that people obey the traffic rules so as to create orderly traffic culture. Options for implementing E-ticket is very effective by utilizing advances in information and communication technology. In terms of efficiency, the E-ticket is very efficient. Without the use of paper all traffic violations recorded by the digital system, thereby reducing the cost of paper as proof of infringement. Violators of traffic rules does not have to commute and to the court to resolve the problem. Because they will be sent a digital notification system, when the case will go to trial. By leveraging technology speeding ticket, the whole process will be more efficient and effective also assist the police in administrative management. Application user is categorized into two, the first is the police and the second is the prosecutors. Through E-ticket will people know all the information about the actions that may constitute violations of traffic as well as the penalties for such actions. So, expect a litigious society and not be in violation again. Another benefit is that terwujud nyatakan transparency and accountability in the attitudes and actions of the police in carrying out the duties and authority of everyday especially in curbing traffic violations.

\section{METHOD}

Qualitative research approach is research that aims to understand the phenomenon of what is experienced by research subjects. The approach used in this study is a qualitative approach, because it describes in the form of words. Based on the type and method of the research, the study aims to outline and describe the implementation of the E-ticket in the city of Bandung. According Arikunto (2006, p. 160), the research method is the means used by researchers to collect data research. The method used in this research is descriptive analysis method. Descriptive analysis method selected in order to provide an overview of the phenomenon that occurs then analyze in depth the rest Nazir (1988, p. 64) explains that:

"Descriptive research includes a broader research method, researchers not only provide an overview of phenomena, but also explain the relationship, to test hypotheses, make predictions, and get the meaning and implications of a masalah are solved".
Nazir claimed that the descriptive method not only describe a phenomenon that occurs but also provides predictive and causal relationship. But the simple Best (in Sukardi) states that 'the descriptive method sought to describe and interpret the object in accordance with what we are. More clearly Sukardi states that "descriptive research is research in which data collection to test the research question or hypothesis relating to the circumstances and current events. They report the state of the object or subject under study in accordance with what is ". data collection techniques are observation, documentation, interviews, library research and the validity of the data using triangulation data.

\section{DISCUSSION}

Many people commit offenses in their daily lives, do not know the young or old, most of the people do breach either at home, school or in the community. Many people who often say the term "that the regulations / laws made for violated". These terms should be eliminated even do not often expressed as considering the rules are made to maintain order and balance in running society, nation and state. It was strengthened by article 1 , paragraph 3 in the Constitution of the Republic of Indonesia Year 1945, which stated that "Indonesia is a country of law". Based on the above statement, indicating that the Indonesian State in all its activities are regulated by law and many rules that govern the public not clashes between communities. Referring to article 1, paragraph 3 in the Constitution of the Republic of Indonesia Year 1945, which stated that Indonesia is a country of law, making the entire people of Indonesia must abide by the rules and not to commit the offense, because the offense would lead to sanctions or penalties and indicate violators are citizens who are not good.

Violations by Sudarto is an action that is known by the public as an offense when such acts, if carried out would get a legal or penalties contained in the legislation [3]. Definition of the offense different from the statements Prodjodkiro which defines infringement as "an act of breaking something and jurisdictional means other than unlawful acts" [4]. Violation in this case is not the same as the crime as proposed by Soekanto describes the traffic offenses as negligent society:

"Who is a traffic violation? The answer is not related to the name or job. Law enforcement should be aware that traffic violations (in most cases) are not criminals, but people who neglect or negligent. Surely that law enforcement must always be prepared for the fact, if it turns out is a criminal offense that is being escaped. However, in general, violations are citizens who are negligent, and therefore make the wrong decision " [5].

Seeing the understanding of the three experts who expressed understanding of violations would have a different viewpoint, where Soekanto emphasized that the violations in particular a traffic violation is a negligent act or omission be emphasized that the offense is an act which if done will be punished. Apart from the various viewpoints of experts associated with the understanding violation, we have to make sure is that people already know and understand the rules and sanction an unlawful act, because people know the rules made 
along with sanctions at least will make people take fastidiously in action and take precautions so that no penalties or sanctions.

Electronic ticket which is called E-ticket is a ticket digitization process, by utilizing the entire process of a speeding ticket is expected to be more efficient and effective also assist the police in administrative management [6]. ETilang is an application that can be used by the community in which you know the cost to be paid directly. Once listed on the application, offenders can choose to use the E-Tilang in the application or user. Application user is categorized into two, the first is the police and the second is the prosecutors. Applications E-Tilang not implement the function as an introduction to pay a fine to the Bank / Registrar because the mechanism involves a form or a paper ticket, the E-Tilang form or paper proof of offenders not in use, this application just send a reminder in the form of ID Tilang which store all data or records police on chronological traffic tickets will be given to the court or the prosecutor who has a website with the same database integration [7].

Some of the benefits for traffic violators with their system E-Tilang are: (a). Transparency. The existence of a mechanism for reporting and dissemination of information of public officials act irregularities in the activities of governance. (b). Empowerment. Through E-Tilang will people know all the information about the actions that may constitute violations of traffic as well as the penalties for such actions. So hopefully people can pass on the attitude of traffic rules after finding out the existing regulations to the people around him in order not to violate the rules. (c). Responsive. The responsiveness of the authorities will be higher and more rapid response and more responsive to public complaints in terms of traffic. (d). Justice. In the service E-Tilang every violation is committing the same offense will get the same fines or penalties indiscriminately.

Definition of legal awareness by Soerjono Soekanto is actually a legal awareness or consciousness of the values contained in a human being on the existing law or of the law to expect there. Actually, the emphasis is on function values of law and not a legal assessment of the concrete events in the community is concerned [8]. while according Sudikno, "Legal Awareness means the consciousness about what we should do or should not do or what we do or do especially against others. This means awareness of our legal obligations of each of the others " [9].

According to. Soerjono there are four indicators that make up the legal awareness in order (step by step), namely: (1). Knowledge of the law; a person's knowledge with respect to certain behaviors governed by written laws, namely about what is forbidden and what is allowed. (2). Understanding of the law; amount of information held by a person regarding the content of the rules (written), namely on the content, purpose, and benefits of the regulation. (3). The attitude of law (legal attitude); is a tendency to accept or reject the law for their awards or conviction that the law is beneficial to the human life. In this case the existing elements of appreciation of the rule of law. (4). The pattern of behavior of the law; on apply whether or not a rule of law in society. If you apply a legal rule, the extent of the entry into force and the extent to which people obey [8].
Cultural elements of citizenship that most central and needs to be developed is a virtue / morality citizenship (civic virtue). What is meant is the willingness of citizens to put the public interest ahead of personal interests (... the willingness of the citizens to set aside private interests and personal concerns for the sake of the common good) [10]. On this Quigley and Bahmueller believe that the virtues of citizenship are an individual psychosocial domain substantively has two elements, namely the nature of citizenship (civic disposition) and commitment to citizenship (civic commitment). Character, citizenship is the attitude and habits of thinking citizens who sustain the development of the social function of healthy and guarantee the common interests of the democratic system (... Reviews those attitudes and habits of mind of the citizen that are conducive to the healthy functioning and common good of the democratic system). Meanwhile, civic commitment is or commitment of citizens to reason and accepted aware of the values and principles of constitutional democracy (... the freely-given, reasoned commitments of the citizen to the fundamental values and principles of constitutional democracy) [10].

\section{CONCLUSION}

E-ticket that has been adopted in porlestabes Bandung which is necessary to reduce traffic violations, because the eticket in the city of Bandung has been used or integrated with CCTV, with their e-ticket making process ticketed more effective, where e-ticket is digitizing ticketed by utilizing the times and technology. by e-ticketed at least able to create legal awareness of traffic increase because people will feel unsupervised while on the road because it has spread cctv at some point in the city of Bandung, in implementing e-ticket in the city of Bandung still require various support from various parties, both in the increased cctv amount that is in the city of Bandung and must increasingly socialize e-ticket program to the general public.

\section{REFERENCES}

[1] Undang-Undang No. 22 Tahun 2009 Tentang Lalu Lintas dan Angkutan Jalan

[2] Winataputra \& Budimansyah, Dasim, Civic Education Konteks, Landasan, Bahan Ajar dan Kultur Kelas. Bandung: Program Studi pendidikan Kewarganegaraan Sekolah Pascasarjana Universitas Pendidikan Indonesia. 2007

[3] Sudarto, Daryanto. Penyaring Perkara Pidana Oleh Polisi. Jakarta: Pradnya Paramita. 1999.

[4] Prodjodkiro, Wirojono. Asas-Asas Hukum Pidana di Indonesia. Bandung: Eresco. 1989.

[5] Soekanto, Soerjono. Polisi dan Lalu Lintas. Bandung: Mandar Maju. 1990.

[6] Sona Seki Halawa, Penerapan Sanksi Denda Tilang Bagi Pelanggar Lalu Lintas Berdasarkan Undang-Undang Nomor 22 Tahun 2009 Tentang Lalu Lintas Dan Angkutan Jalan Di Wilayah Hukum Kepolisian Resor Kota Pekanbaru. 2015.

[7] Subhave Sandhy, Suwarto H, Arie Q. Aplikasi Tilang Berbasis Android. Universitas Ilmu Pakuwan Bogor. 2016.

[8] Soerjono Soekanto, Faktor-faktor yang Mempengaruhi Penegakan Hukum, Jakarta : Raja Grafindo Persada. 2004 
[9] Sudikno Mertokusumo, Meningkatkan Kesadaran Hukum Masyarakat, Edisi Pertama, Yokyakatra : Liberti. 1981.
[10] Quigley, C. N., \& Bahmueller, C. F. Civitas: A Framework for Civic Education. Calabasas: Center for Civic Education. 1991. 